\title{
General practitioners' continuing medical education within and outside their practice
}

\author{
Penny A Owen, Lynne A Allery, Keith G Harding, Tom M Hayes
}

\begin{abstract}
To study continuing medical education 96 out of 101 general practitioners chosen at random from the list held by a family practitioner committee were interviewed. The results provided little evidence of regular attendance at local postgraduate centre meetings, though practice based educational meetings were common. Thirty one of the general practitioners worked in practices that held one or more practice based educational meetings each month at which the doctors provided the main educational content. Performance review was undertaken in the practices of 51 of the general practitioners, and 80 of the doctors recognised its value. The general practitioners considered that the most valuable educational activities occurred within the practice, the most valued being contact with partners. They asked for increased contact with hospital doctors.
\end{abstract}

The development of general practitioners' continuing medical education should be based on the content of the individual general practitioner's day to day work and entail contact with his or her professional colleagues.

\section{Introduction}

Considerable interest is being shown in how general practitioners keep up to date. The white paper on primary care discussed the importance of continuing relevant medical education and suggested a new postgraduate allowance for those doctors who maintain a regular programme of education and training throughout their careers.' The, Royal College of General Practitioners published an occasional paper on continuing education for general practitioners, in which it investigated attendance at continuing education meetings. ${ }^{2}$ Other studies have also described general practitioners' attendance at meetings. ${ }^{3+}$

We present the results of a survey of a range of activities that make up continuing medical education for general practitioners. We ascertained the extent and pattern of continuing medical education both within and outside the practice of a random sample of general practitioners; obtained more detailed information on practice based educational meetings; investigated the extent of participation of drug companies in general practitioners' continuing medical education; and obtained general practitioners' suggestions for improvements in that education.

\section{Subjects and methods}

We chose a random sample of 101 general practitioners from the list held by a family practitioner committee in January 1988. This represented $45 \%$ of the general practitioners on the list. A letter explaining the study was sent to each of the general practitioners, and they were asked if they would be willing to be interviewed about their continuing medical education. An independent research company undertook the interviews, and the interviewers were briefed by one of us. If a general practitioner declined to be interviewed by the research company he or she was given the opportunity to be interviewed by PAO or $\mathrm{KGH}$. The interviews took place in the general practitioners' surgeries. They lasted about 30 minutes and were conducted in April and May 1988. We had designed a semistructured questionnaire for the survey, which had been piloted among general practitioners from outside the family practitioner committee area. We analysed the data with the statistical package for the social sciences (SPSSX).

\section{Results}

Ninety six of the 101 general practitioners were interviewed. The research company interviewed 86 doctors, and we interviewed 10. The interviewed general practitioners came from six of the 13 singlehanded practices and 50 of the 61 partnerships in the family practitioner committee's area.

Attendance at meetings at local postgraduate centresIn the academic year 1987-8 the local postgraduate centre organised the following activities for general practitioners: 26 lunchtime meetings; nine half day or day long symposiums; a refresher course lasting one week; and a course on practical procedures. Seventy two general practitioners had attended a lunchtime meeting at some time, with 18 having attended half or more of the meetings held in the past year. Sixty nine had attended at least one symposium at some time, and 39 had attended two or more within the past year. Thirty had attended one of the refresher courses at some time.

Educational meetings within the practice-We classified the educational meetings within practices into two categories: firstly, those for which the general practitioners provided the main educational content of the meetings and, secondly, those for which drug companies provided the main educational content. Forty four doctors worked in practices that had held an educational meeting at which the general practitioners provided the main content, with 31 working in practices that held one or more such meetings a month. Eighty six doctors worked in practices that had held an educational meeting at which a drug company provided the main content, with 37 working in practices that held one or more such meetings a month.

Drug companies' meetings and other meetings outside the practice - Seventy three general practitioners had attended one educational meeting outside the practice organised by a drug company and 55 had attended three or more meetings of this kind within the past year. The general practitioners were asked if they attended any other educational meetings outside the 
practice that were not organised by the local postgraduate centre or by drug companies. Forty seven participated in one of the local medical societies, 41 took part in a special interest group of the Royal College of General Practitioners, 19 had attended a young principals group, and 18 mentioned trainers' workshops.

Medical journals, books, and libraries-The general practitioners were asked to describe how thoroughly they read certain journals and medical papers that we had selected to represent the various types of reports available to them. Table I shows their replies. The

TABLE I-Number of general practitioners reading journals and medical papers

\begin{tabular}{|c|c|c|c|}
\hline & $\begin{array}{l}\text { Do not look } \\
\text { at them }\end{array}$ & $\begin{array}{c}\text { Read } \\
\text { selectively }\end{array}$ & $\begin{array}{c}\text { Read } \\
\text { thoroughly }\end{array}$ \\
\hline Drugs and Therapeutics Bulletin & 3 & 64 & 27 \\
\hline Update & 24 & 62 & 10 \\
\hline British Medical fournal & 23 & 63 & 10 \\
\hline $\begin{array}{c}\text { Fournal of the Royal College of } \\
\text { General Practitioners }\end{array}$ & & 31 & 8 \\
\hline General Practitioner & $\begin{array}{r}50 \\
7\end{array}$ & $\begin{array}{l}31 \\
59\end{array}$ & 20 \\
\hline
\end{tabular}

general practitioners were asked how many medical books they had bought for their personal use in the past year. Sixty one had bought between one and five books, and 12 had bought six or more. Eighty doctors reported that their practice had a library, 35 of the 80 had added between one and five books to the library during the past year, and 36 had added six or more books.

Performance review within the practice-The general practitioners were asked if their practice ever reviewed how patients were managed, assessed clinical practice, or reviewed clinical care. Fifty one replied that they carried out such reviews. They described activities such as reviews of cytology services, uptake of immunisation, prescribing habits, diabetic and hypertensive patients, use of tranquillisers, and contraceptive services.

General practitioners' assessment of the value of continuing medical education-The general practitioners were shown a list of 15 continuing medical education activities and asked to rate each one on a scale from 1 to 5,1 being very valuable and 5 of no value. Table II shows the five educational activities that the highest numbers of general practitioners rated as very valuable.

TABLE II -General practitioners' "top five” educational activities

\begin{tabular}{lc}
\hline Educational activity & $\begin{array}{c}\text { No rating } \\
\text { activity as } \\
\text { very valuable } \\
\text { (n=95) }\end{array}$ \\
\hline $\begin{array}{l}\text { Contact with partners, such as practice meetings and } \\
\text { discussions }\end{array}$ & 60 \\
$\begin{array}{l}\text { Contact with patients } \\
\text { Practice meetings with health visitors, district nurses, }\end{array}$ & 41 \\
$\quad$ ocial workers, etc & 29 \\
$\begin{array}{l}\text { Postgraduate meetings based at local hospitals, courses, } \\
\text { and symposiums }\end{array}$ & 27 \\
$\begin{array}{l}\text { Informal hospital input, such as contact with consultants, } \\
\text { discharge summaries, etc }\end{array}$ & 24 \\
\hline
\end{tabular}

The 10 other activities were reading medical literature; lectures; visits to other practices; local medical societies and special interest groups; educational aids such as videotapes produced by the Open University or television programmes; educational events organised by drug firms; discussion groups; visits by drug representatives; engaging in a research topic; and young principals groups. When given a list of four formal educational activities 48 said that a discussion group was their preferred learning method, 27 chose lectures by consultants, 11 chose reviews of clinical care, and five chose lectures by general practitioners.
General practitioners' attitudes to selected issues-The general practitioners were presented with pairs of positively and negatively worded statements relating to current issues in continuing medical education. On the question of whether non-medical members of the primary health care team should take part in general practitioners' continuing medical education, 71 general practitioners thought that they should and seven that they should not. Sixty seven general practitioners agreed that there should be joint educational activities with hospital doctors. Eighty general practitioners thought that reviews of clinical care should be an important part of continuing medical education. Fifty five general practitioners thought that self learning activities on their own were an inadequate method of continuing medical education. Twenty seven general practitioners were satisfied with the continuing medical education available to them, while 36 thought that improvements were necessary.

General practitioners' suggestions for improvementThe general practitioners were asked to describe two or three activities or resources that they thought would improve continuing medical education. Thirty one thought that there should be an increase in the resources available. Suggestions ranged from more videotapes and libraries to facilities to promote performance review in practice, peripatetic tutors for practices, resources to promote research in general practice, and financial help to buy protected time to attend meetings. Thirty general practitioners suggested that continuing medical education might be improved if there were more contact with hospital staff.

\section{Discussion}

In this study most general practitioners had attended at least one meeting organised by the local postgraduate centre, but there was little evidence of regular attendance. Educational meetings within the practice constitute a substantial part of current continuing medical education, with about one third of general practitioners working in practices that hold one or more meetings a month at which the general practitioners provided the educational content.

The Royal College of General Practitioners recognised the importance of performance review with the publication of its recommendations for promoting quality in general practice. ${ }^{6}$ This policy statement contained as its two principal aims that each general practitioner should, firstly, describe his or her current work and, secondly, define specific objectives for the care of his or her patients and monitor the extent to which these are met. With just over half of the general practitioners reporting that their practices carried out performance review this is encouraging evidence that the importance of reviewing their everyday clinical work is now appreciated by a substantial number of general practitioners. One of the challenges for the organisers of continuing medical education is to provide all practices with the help they may need to undertake performance review and any consequent educational input.

When asked to rate the value of various activities the three educational activities that the highest numbers of general practitioners rated as very valuable all occurred within the practice. Communication between partners and with other members of the primary health care team is therefore considered to be of major importance in continuing medical education by general practitioners and is more highly valued than activities that occur outside the practice. The value of continuing medical education based on both the doctor's own work and contact with colleagues has been documented. ${ }^{7-11}$

We have based several recommendations on the 
findings of this study. Firstly, local postgraduate centres should provide a range of meetings and activities from which the general practitioners can choose to attend those that are of interest to them. Secondly, contact between general practitioners and hospital doctors must be improved. Possible ways of doing this are to increase the number of meetings between general practitioners and hospital doctors organised by local postgraduate centres; to encourage hospital doctors to visit practices to participate in practice based educational meetings; and to increase the opportunities for general practitioners attending at outpatient clinics. Thirdly, practices should be encouraged to improve communication between team members. Fourthly, further research should be undertaken into the role of drug companies at practice based educational meetings. Finally, while all doctors are responsible for their own continuing education, any new postgraduate education allowance should recognise the broadly based nature of continuing medical education for general practitioners - namely, that it occurs both within and outside the practice and concerns a wide range of staff including practice partners, hospital doctors, and members of the primary health care team. Continuing medical educa- tion for general practitioners cannot be successful if it is totally isolated from the continuing education of the rest of the medical or associated professions.

We thank the general practitioners whose participation made this study possible.

1 Department of Health and Social Security. Promoting better health. London: HMSO, 1987. (Cmnd 249.)

2 Branthwaite A, Ross A, Henshaw A, Davie C. Continuing education for general practitioners. London: Royal College of General Practitioners, 1988. (Occasional paper 38 .)

3 Wood J, Byrne PS. Section 63 activities.London: Royal College of General Practitioners, 1980. (Occasional paper 11.)

4 Reedy BLEC, Gregson BA, Williams M. General practitioners and postgraduat education in the Northern region. London: Royal College of General Practieducation in the Northem region. Lond

5 Reiss BB, Berrington RM, Stuart DRM, Tait IG. Practice educational meetings; a new influence in general practice. $B r M c d f$ 1981;283:1025-7.

6 Royal College of General Practitioners. Quality in general practice. London: RCGP, 1985. Policy statement 2.)

7 Schofield TPC. Continued medical education must not be an optional extra. BrMed f 1987;294:526-7.

8 Alment EAJ. Competence to practise. London: Committee of Enquiry into Competence to Practise, 1976:16.

9 Pickering G. Quest for excellence in medical education. Oxford: Oxford University Press, 1978:34.

10 Muir Gray J. Continuing education: what techniques are effective? Lance 1986;ii:447-8.

11 Horder J, Bosanquet N, Stocking B. Ways of influencing the behaviour of general practitioners. $\mathcal{F}$ R Coll Gen Pract 1986;36:517-21.

Accepted 12 fune 1989

\section{BOOKS RECEIVED}

\begin{abstract}
Haematology
The Johns Hopkins Series in Contemporary Medicine and Public Health. "Bone Marrow Diagnosis in Clinical Practice." H Brücher. Translated by $\mathrm{E}$ Kucera. (Pp xi+254; figs; £48.) Baltimore: Johns Hopkins University Press, 1989. ISBN 0-8018-3468-6. Recent Advances in Haematology. Vol
5. Ed A V Hoffbrand. (Pp xii +333 ; 5. Ed A V Hoffbrand. (Pp xii +333 ;
figs; £40.) Edinburgh: Churchill figs; $\{40$.) Edinburgh: Churchill
Livingstone, 1988. ISBN 0-443Livingsto
03997-6.

\section{Nutrition}

Don't Eat Your Heart Out. J C Piscatella. (Pp 304; $£ 5.99$ paperback.) Wellingborough: Thorsons, 1989. Wellingborough: Thor

EURO-NUT Report 11. "Nutrition and the Elderly." Ed L de Groot, W A van Staveren. (Pp 131; figs; \$7 paperback, including postage and packing.) Wageningen: EURO-NUT, 1988. Obtainable from the publisher, c/o Department of Human Nutrition, Wageningen Agricultural University, Bomenweg 2, 6703 HD Wageningen, The Netherlands. ISBN 90-72448-022.
\end{abstract}

\section{Obstetrics and gynaecology}

Contributions to Gynecology and Obstetrics. Vol 17. "Achievements in Gynecology." Ed S Mancuso. Series editor P J Keller. (Pp 128; figs; £44.60.) editor P J Keller.(Pp 128; figs; $\{44.60$.) Basle: Karger, 1989. Distributed
by John Wiley and Sons. ISBN by John Wiley

\section{Oncology}

IARC Monographs on the Evaluation of Carcinogenic Risks to Humans. Vol 44. "Alcohol Drinking." International Agency for Research on Cancer. (Pp 416; Sw frs 65 paperback.) Geneva: World Health Organisation, 1988. ISBN 92-832-1244-4.

\section{Orthopaedics}

A New Short Textbook of Orthopaedics and Traumatology. S Hughes. (Pp ix + 236; figs; 215.95 paperback.) Londo Arnold, 1989. ISBN 0-340-41773-0.

\section{Paediatrics}

Classics in Developmental Medicine. No 3. "The Embryology of Behaviour: the
Beginnings of the Human Mind." A Gesell in collaboration with $\mathrm{C}$ S Amatruda. Series editor R G Mitchell. (Pp xxi+274; figs; £20.) London: Mac Keith Press, 1989. Distributed by Blackwell Scientific. ISBN 0-632 02314-7.

\section{Pharmacology}

Design of Enzyme Inhibitors as Drugs. Ed M Sandler, H J Smith. (Pp xviii 810; figs; £90.) Oxford: Oxford University Press, 1989. ISBN 0-19 261537-8. Medicines: Regulation, Research and
Risk. Ed J P Griffin. Executive editors P F D'Arcy, D W G Harron. (Pp xii + P F D'Arcy, D W G Harron. (Pp xii +
304; figs; £50.) 1989. Available from Dr Dean Harron, Department of Dr Dean Harron, Department of
Pharmacology, Queen's University of Pharmacology, Queen's University of
Belfast, Belfast, N Ireland. ISBN 085389-325-X.

\section{Pharmacology - clinical}

Neurotransmitters, Drugs and Disease. Ed R A Webster, C C Jordan. ( $\mathrm{P}$ xiv +474 ; figs; $\{19.50$ paperback.) Oxford: Blackwell Scientific, 1989 ISBN 0-632-00717-6.

Receptor Biochemistry and Methodology. Vol 13. "Receptor Localization: Ligand Autoradiology." Ed F M Leslie, C A Altar. Series editors J C Venter, L C Harrison. (Pp ix +226 ;
figs; $\$ 79.50$.) New York: Liss, 1988. figs; $\$ 79.50$.) New York: Liss, 1988 .
Distributed by John Wiley and Sons. Distributed by John
ISBN 0-8451-3712-3.

\section{Psychiatry}

Fighting with Food: Overcoming Bulimia Nervosa. G F Huon, L Brown. (Pp vii +123 ; figs; price not stated, paperback.) Kensington NSW : New South Wales University Press, 1988. ISBN 0-86840-051-3.

Reshaping the Psychoanalytic Domain. the Work of Melanie Klein, $W R D$ the Work of Melanie Klein, W $R D$
Fairbairn, and $D W$ Winnicolt. J M Fairbairn, and $D W W$ Winnicolt. J M
Hughes. (Pp xii $+244 ; \$ 30$.) Berkeley: Hughes. (Pp xii $+244 ; \$ 30$.) Berkeley:
University of California Press, 1989.

\section{Psychology}

An Introduction to Clinical Child Psychology. Ed S J E Lindsay, G E Powell. (Pp x $+341 ;$ £35.) Aldershot Gower, 1989. ISBN 0-566-05103-6.

Introduction to Psychosexual Medicine: for Doctors, Nurses, Students and Other Health Care Professionals. Ed R L Skrine. (Pp 211; £10.95 paperback.) Carlisle: Montana Press, 1989. ISBN 1-870786-05-X.

Problems in Practice. "Facing Physical Violence." G M Breakwell. (Pp xi+97; £5.95 paperback.) London: British Psychological Society and Routledge, 1989. ISBN 0-901715-95-6.

Problems in Practice. "Managing Stress." D Fontana. (Pp ix +114 index; $£ 5.95$ paperback.) London British Psychological Society and Routledge, 1989. ISBN 0-901715-97 2.

Psychotherapy in Britain. "Group Therapy in Britain." Ed M Aveline, W Dryden. Series editor W Dryden. (Pp Dryden. Series editor $W$ Dryden. (Pp
xii $+346 ; £ 12.50$ paperback.) Milton Xi1 +346; $£ 12.50$ paperback.) Milton Keynes: Open Univer
ISBN 0-335-09829-0.

Psychoanalysis and Groups: History and Dialectics. D Rosenfeld. (Pp xvii +190 114.95 paperback.) London: Karnac Books, 1989. ISBN 0-946439-48-6.

Radiology

Imaging Techniques in Orthopaedics. Ed C S B Galasko, I Isherwood. (Pp xi376; figs; £75.) London: Springer, 1989. ISBN 3-540-19523-8.

NCRP Report No. 99. "Quality Assurance for Diagnostic Imagin Equipment."Recommendations of the National Council on Radiation Protection and Measurements. (Pp xiii +250 $\$ 18$ paperback.) Bethesda: National Council on Kadiation Protection an Measurements, 1988. ISBN 0-92960000-2.

\section{Rehabilitation}

Muscles, Nerves and Movement: Kinesology in Daily Living. B Tyldesley, J Grieve. (Pp x +325; figs; §14.95 paperback.) Oxford: Blackwell Scientific, 1989. ISBN 0-632-01643-4

\section{Respiratory medicine}

Human Horizons Series. "Cystic Fibrosis: a Guide for Parents and Sufferers." P Bray. (Pp ix + 181; figs; $£ 7.95$ paperback.) London: Souvenir Press, 1989 ISBN 0-285-65076-9.

Lung Biology in Health and Disease. Vol 38. "Pulmonary Vascular Physiology and Pathophysiology." Ed E K
Weir, J T Reeves. Executive editor C Lenfant. (Pp xvi +762 ; figs; $\$ 150$.) New York: Dekker, 1989. ISBN 08247-7972-X.

Lung Biology in Health and Disease. Vol 40. "Respiratory Physiology: an Analytical Approach." Ed H K Chang, M Paiva. Executive editor C Lenfant.
(Pp xv+869; figs; $\$ 180$.) New York: Dekker, 1989. ISBN 0-8247-7855-3.

\section{Sociology}

It's My Duty, Isn't It? The Plight of Carers in Our Society. J Pitkeathley. (Pp 180; £7.95 paperback.) London: Souvenir Press, 1989. ISBN 0-28562885-2.

\section{Sports medicine}

High Altitude Medicine and Physiology. M P Ward, J S Milledge, J B West. (Pp xviii +515 ; figs; £50.) London: Chapman and Hall, 1989. ISBN 0412-29010-3.

\section{Surgery}

Cutaneous Electrosurgery. J E Sebben. (Pp $\mathrm{x}+211$; figs; 141.50 .) Chicago: Year Book Medical, 1989. Distributed by Wolfe Medical. ISBN $0-8151$ 7804-2.

Flaps and Grafts in Dermatologic Surgery. TA Tromovitch, S J Stegman, R G Glogau. (Pp xvii + 240; figs; £45.) Chicago: Year Book Medical, 1989. Distributed by Wolfe Medical. ISBN 0-8151-8849-8

A Guide to Practical Procedures in Medicine and Surgery. H A F Dudley, J R T Eckersley, S Paterson-Brown. J R T Eckersley, S Paterson-Brown.
Illustrations by G Lee. (Pp viii +179 ; figs; $\{12.50$ paperback.) London: figs; $£ 12.50$ paperback.) London: 433-00058-9.

Piccin Surgical Technique Series. Vol 14. "Surgery of the Peripheral Nerves." G Morello, F Pluchino. General editor C Cordiano. (Pp viiit 392; colour plates; lire 312.500 . Padua: Piccin, 1988. ISBN 88-2990231-4

Rush University Review of Surgery. S G Economou, S D Bines, D J Deziel, TR Witt. (Ppxviii + 426; £16.95 paper back.) Philadelphia: Saunders, 1988 Distributed by Harcourt Brace Jovanovich. ISBN 0-7216-2070-1. 